\title{
Trace of heavy metals in maternal and umbilical cord blood samples in association with birth outcomes in Baghdad, Iraq
}

\author{
Mayyadah Hasan Rhaif Al-Sahlanee ${ }^{1,2, *}$, Ramzun Maizan Ramli ${ }^{1}$, Miami Abdul Hassan \\ Ali $^{3}$, Nada Fadhil Tawfiq ${ }^{4}$, Nurul Zahirah Noor Azman ${ }^{1}$, Azhar Abdul Rahman ${ }^{1}$, Iskandar \\ Shahrim Mustafa ${ }^{1}$, Nik Noor Ashikin Nik Abdul Razak ${ }^{1}$, Nor Zakiah Yahaya ${ }^{5}$, Hana \\ Mohammed Al-Marri ${ }^{1}$, Nur Syuhada Ayob ${ }^{1}$ and Nabela Zakaria ${ }^{1}$ \\ ${ }^{1}$ School of Physics, Universiti Sains Malaysia, 11800 Pulau Pinang, Malaysia \\ ${ }^{2}$ Department of Physiology, College of Medicine, AI-Mustansiriya University, Baghdad, Iraq \\ ${ }^{3}$ Department of Obstetrics \& Gynecology, College of Medicine, AL- Mustansiriya University, \\ Baghdad, Iraq \\ ${ }^{4}$ Department of Physics, College of Science, AI-Nahrain University, Baghdad, Iraq \\ ${ }^{5}$ School of Distance Education, Universiti Sains Malaysia, 11800 Pulau Pinang, Malaysia
}

\begin{abstract}
Trace elements are essential nutritional components in humans and inconvenient tissue content that have a significant influence on infant size. The aim of this study is to evaluate the effects of concentration of elements (uranium $(\mathrm{U})$, lead $(\mathrm{Pb})$ and iron $(\mathrm{Fe}))$ and absorption of $\mathrm{Pb}$ and $\mathrm{Fe}$ on maternal and umbilical cord blood samples. The concentration and absorption of $\mathrm{Pb}$ and $\mathrm{Fe}$ in blood samples were determined by using atomic absorption spectrophotometry device, while the uranium concentration was determined by using CR-39 detector. Fifty women of age 16-44 years are involved in this study. Results show that the maximum and minimum values of both concentration and absorption in the maternal samples were for $\mathrm{Pb}$ and $\mathrm{Fe}$, respectively. In addition, for umbilical cord, the maximum values of concentration and absorption were for $\mathrm{Fe}$ and the minimum concentration and absorption were for $\mathrm{U}$ and $\mathrm{Pb}$, respectively. A significant correlation between maternal and umbilical cord blood samples was found. This indicates that the $\mathrm{Pb}, \mathrm{U}$ and Fe elements can easily transfer from maternal to the fetal body which impacts the growth of fetus.
\end{abstract}

Key words: heavy elements; uranium; lead; iron; maternal; umbilical cord; birth outcomes, Baghdad, Iraq.

\footnotetext{
*Corresponding author : mayadahhassen73@yahoo.com
} 


\section{Introduction}

The knowledge obtained from various studies has explain that intrauterine life plays a key role in the evolution of chronic disease in adulthood. The concept suggests that early life conditions can "program" the infants for a spectrum of reverse health outcomes [1-6]. infant growth depends fundamentally on genetic structure, fetoplacental circulation and maternal nutrition[7]. This growth is especially volatile to the impact of environmental risk factors that deactivate the processes during a critical window of susceptibility $[8,9]$. The trace elements of $\mathrm{Pb}, \mathrm{Fe}$ and $\mathrm{U}$ are involved in the function of several enzymes and are essential for maintaining health throughout life [10] While, trace elements are fundamental for humans, their particular function are not well understood, especially in the prenatal interval. Even though their amounts are very small in body, they are implicated in various biochemical passageway and are climacteric to the execution of confirmed functions that are necessary to tolerate life [11].

Radiation risks are mostly significant during organogenesis and the early fetal growth period. It induced deformation have a threshold of 100-200 mGy or higher, and are typically associated with central nervous system problems. This happens especially during exposure at 8 to 25 weeks of gestation age [12]. Even at low levels, fetuses are known to be highly volatile to chemical exposure because of their prompt growth, small size, expansion, and restricted purview to dragging mischievous materiality, in comparison with adults [13]. Elements from the maternal can facilely thread into the placenta and transfer to the infants. This makes the infants volatile to metal toxicity $[14,15]$. Therefore, even low level mineral exposure early in life, at levels that may not prejudice the pregnant mother, could vandalize fetus growth and development [16]. Furthermore, levels of some metals in blood increase during pregnancy, due to increase in bone rampage [17, 18], and increased of gastrointestinal absorption [19].

Devastation of many military institutions and research center in Iraq after the Gulf war 1991 have caused pervasion of many toxic metals and radioactive source. This has made ordinary people prone to radioactive radiation and toxic elements without their awareness or caution. Millions of Iraqi received higher dose of radioactivity than ordinary background levels which is caused by the pollution of depleted uranium [20], and another significant pollution in the environment is contamination of toxic metals such as lead elements as a result of the human activities and military bombardment [21].

There are numbers of studies published in developing countries that have estimated the effect of trace elements levels on maternal and umbilical cord blood. In Iraq very few studies were published covering population [22-25] In previous studies different concentrations of trace elements such as uranium $(\mathrm{U})$, Lead $(\mathrm{Pb})$ and iron $(\mathrm{Fe})$ have been found in maternal blood and umbilical cord, showing a conflicting cohort with the anthropometric characteristics of the infants [26-35] Several factors may participate to the contradiction in those results from previous studies, such as diversity of the study designs and techniques used, heterogeneity in populations and among others.

The present study is the first report of a cross sectional analysis of heavy elements concentration and absorption as well as uranium concentration in maternal and umbilical cord blood samples at the time of delivery in Baghdad. It aims to determine the presence of correlation between maternal and umbilical cord among pregnant women and the association of lead, uranium and iron with birth outcomes, attending Baghdad maternity hospitals for delivery and correspond potential predictors that may influence both levels. 


\section{Materials and Method}

\subsection{Blood Collection}

The population for this study involved 50 volunteers (mother - neonate) pairs at accouchement period. The blood samples of maternal and umbilical cord after delivery were collected from all the participants. The maternal blood was collected at the interval of delivery through a venipuncture, and the umbilical cord blood was collected from the placental end without milking the cord.

The blood samples are divided into 2 aliquots. Half of the blood sample were transferred to a EDTA (ethylene diamine tetra acetic acid) heparin containing evacuated tube and used to determine hemoglobin and $\mathrm{U}$ concentrations.

The other half of the blood samples were transferred into SSTS (serum separating tubes) and were centrifuged for $10 \mathrm{~min}$ to separate the plasma. By using a pipette, $4 \mathrm{ml}$ of plasma was placed in a $7 \mathrm{ml}$ polyethylene tubes for the trace metals analysis. These tubes were frozen for storage and freightage to the laboratories.

Serum separated was used for the estimation of $\mathrm{Pb}$ and Fe concentrations and absorption by using atomic absorption spectrophotometry AA-7000 Series. Meanwhile, the U concentration in blood was determine by using CR-39 detector.

\subsection{Interview}

The interview with each of the respondent was done after delivery. Necessary approval was obtained from them, while information such as health status. Background information were taken, such as health status, nutritional status, intake of Fe during antenatal period, information regarding the previous pregnancies, socio demographic characteristics data (e.g., maternal age, place of living, education, work status, husband work status, tobacco smoking for women and her husband, occupational history, parity of mothers, gestational age which was estimated by using the date for the last menstrual period (LMP), any apparent congenital malformations), information about hemoglobin, blood pressure throughout pregnancy, height and weight. The maternal with hemoglobin $<10.0 \mathrm{~g} / \mathrm{dL}$ were considered as anemic.

\subsection{Measurements outcome birth}

Birth outcomes includes birth weight, birth length, head circumference, placenta weight, sex, and Apgar scores were measured after delivery. For the purpose of analysis, low birth weight infants are considered for birth weight $<2.500 \mathrm{Kg}$, and preterm delivery was defined as a birth before 35 completed weeks of GA.

\subsection{Irradiation of blood samples}

The $\mathrm{U}$ concentrations was determined by heating up the blood samples at $37^{\circ} \mathrm{C}$ for $24 \mathrm{~h}$, using an electric heating incubator type (um100, Memmert, Germany) in order to dry up and oxidize the organic materials. Dried powder blood of $0.5 \mathrm{~g}$ was mixed with $0.1 \mathrm{~g}$ of methylcellulose $\left(\mathrm{C}_{6} \mathrm{H}_{10} \mathrm{O}_{5}\right)$ which was as a sheath. Then, it was pressed into a pellet which has a dimension of $1 \mathrm{~cm}$ diameter and $1.5 \mathrm{~mm}$ thickness. The standard blood samples of different $U$ concentration were prepared. Both sides of the pellets were covered with plastic nuclear track detector (CR - 39 Pershore Moulding Ltd, UK) in thickness of $500 \mu \mathrm{m}$. 
In order to cause inherent damage to the CR-39 detector due to ${ }^{235} \mathrm{U}$ (n, f) reaction with the neutron flounce $\left(3.024 \times 10^{9} \mathrm{ncm}^{-2}\right)$, the sample was irradiated by using thermal neutrons from $\mathrm{Am}-\mathrm{Be}$ neutron source for one week. After irradiation, the CR-39 detectors were etched in $6.25 \mathrm{~N}$ of $\mathrm{NaOH}$ at temperature of $60{ }^{\circ} \mathrm{C}$, approximately for $5 \mathrm{hr}$.

The optical microscope (MT 4310H, Meiji, Japan) with magnifications of up to 400x and eye piece of $10 x$, was used to measure number of track density. It was connected with an optical camera to observed the tracks. The track density $(\rho)$ calculation from eq. (1)

$$
\text { Track density }(\rho)=\frac{\text { average of total pits (tracks) }}{\text { area of field view }}
$$

\subsection{Calculations of Uranium concentrations}

The $\mathrm{U}$ content in the blood samples was measured by rapprochement between track densities recorded on the CR-39 detectors around the sample pellet and that of the standard samples pellet, from the following relationship [36, 37]:

$$
\frac{\text { Cx (sample })}{\rho x(\text { sample })}=\frac{\text { Cs }(\text { standard })}{\rho s(\text { standard })}
$$

Where $\rho x$ and $\rho s$ are the encourage fission track density for unknown sample and standard sample in (tracks $\left./ \mathrm{mm}^{2}\right) . C x$ and $C s$ indicate the $U$ concentration for unknown sample and standard sample in (ppm).

\subsection{Statistical analysis}

The result obtained in this study were analyzed by using Statistical Package for the Social Sciences (SPSS) version 24.0. Descriptive statistics is used to find the frequencies of the values. A Spearman correlation coefficient is used to correlate the maternal and umbilical cord blood of trace elements concentration and absorption. Linear regression model is used to describe the relationship between trace elements and fetal growth. If $p<0.05$ or $<0.01$ it is scrutinized as significant, and if $\mathrm{p} \geq 0.05$, it is scrutinized as non-significant.

\section{Results and discussion}

This population is generally of different socio-economic status and had no receding history of occupational exposure to toxic elements, and also did not take Fe supplementation externally. Table 1 shows the respondents' demographic characteristics. A total of 50 maternal with their infant ( 25 males and 25 females) were analyzed for current study. These women are healthy and free from any diseases of asthma, hypertension, diabetes, heart problem, Thalassemia, thyroid, gastric, Hepatitis B and C, anemia epilepsy, migraine, renal and TB.

The women involved in this study were aged from 16 to 44 years old. $76 \%$ of maternal had high school and higher education, while $24 \%$ had less than high school. The percentage of maternal that smoke is $12 \%$ during pregnancy. The rates of preterm birth, low birth weight and low Apgar Score were 6\%, 14\% and 85\%, respectively.

The maternal and infant quantitative characteristics at delivery period show in Table 2 the mean value of age is $(33.3 \pm 7.6$ years), body mass index (BMI; weight in kilograms/height in square meters) with mean value $\left(30.7 \pm 4.8\left(\mathrm{~kg} / \mathrm{m}^{2}\right)\right.$, maternal hemoglobin $(9.41 \pm 1.80$ 
$\mathrm{g} / \mathrm{dL})$, umbilical cord hemoglobin $(9.40 \pm 1.74 \mathrm{~g} / \mathrm{dL})$, systolic and diastolic blood pressure $(117.0 \pm 10.2,74.1 \pm 6.2 \mathrm{mmHg}$ respectively $)$, pregnancy heart rate and fetal heart rate were $(101.0 \pm 22.2,120.0 \pm 5.3 \mathrm{bpm}$ respectively). The mean gestational age (GA) at delivery was $(38.6 \pm 1.3$ weeks) and the anthropometric measurements (Birth weight, Birth length, Head circumference and placenta weight) are $(2.94 \pm 0.93,39.02 \pm 6.8,35.5 \pm 2.3$ and $481.05 \pm 201.58$ respectively).

Table 1. Socio-demographic characteristics

\begin{tabular}{|c|c|c|c|c|}
\hline \multicolumn{3}{|c|}{ Characteristics } & \multirow{2}{*}{$\begin{array}{l}\mathbf{N} \\
17 \\
\end{array}$} & \multirow{2}{*}{$\begin{array}{c}\text { percentage } \\
34\end{array}$} \\
\hline \multirow[t]{14}{*}{ Maternal } & \multirow[t]{2}{*}{ Age } & $<30$ years old & & \\
\hline & & $\geq 30$ years' old & 33 & 66 \\
\hline & \multirow[t]{3}{*}{ Education } & Less than high school & 12 & 24 \\
\hline & & High school graduate & 22 & 44 \\
\hline & & Higher education & 16 & 32 \\
\hline & \multirow[t]{2}{*}{ Working status } & Yes & 30 & 60 \\
\hline & & No & 20 & 40 \\
\hline & \multirow{2}{*}{$\begin{array}{l}\text { Husband working } \\
\text { status }\end{array}$} & Yes & 44 & 88 \\
\hline & & No & 6 & 12 \\
\hline & \multirow[t]{3}{*}{ Smoking } & Yes & 6 & 12 \\
\hline & & No & 37 & 74 \\
\hline & & Past & 7 & 14 \\
\hline & \multirow{2}{*}{ Parity } & 0 & 21 & 42 \\
\hline & & 1or more & 29 & 58 \\
\hline \multirow[t]{9}{*}{ Infant } & \multirow[t]{2}{*}{ Gender } & Male & 25 & 50 \\
\hline & & Female & 25 & 50 \\
\hline & \multirow[t]{2}{*}{ Birth Weight } & $\leq 2.5 \mathrm{~kg}$ & 7 & 14 \\
\hline & & $>2.5 \mathrm{~kg}$ & 43 & 86 \\
\hline & \multirow[t]{3}{*}{ GA at delivery } & Pre - Term $<35$ & 3 & 6 \\
\hline & & Early - Term (37-39) & 20 & 40 \\
\hline & & Full term $\geq 39$ & 27 & 54 \\
\hline & \multirow{2}{*}{$\begin{array}{l}\text { 5-min Apgar } \\
\text { score }\end{array}$} & $<5$ & 47 & 85 \\
\hline & & $\geq 5$ & 3 & 15 \\
\hline
\end{tabular}

Table 3 and Figure 1 show the elements concentration in maternal and umbilical cord blood samples. The maximum value obtained was $1.27 \mathrm{ppm}$ which represents to iron concentration in umbilical cord blood samples, and the minimum value of concentration is $0.50 \mathrm{ppm}$ for the concentration of iron in maternal blood samples. The concentration of iron in umbilical cord as higher than in maternal blood samples. This indicate that the infants receive iron indirectly from their mother's blood circulation through a prompt and unidirectional passageway.

In maternal the highest levels of elements were recorded in lead level. These higher values could be caused by human activities, industrial wastes resulting from the petroleum, military events during the Gulf wars, and prevailing petrochemical industries in these governorates. Iraq is one of the third-world countries confronting terrifying environmental problems. The use of leaded gasoline, untreated sewage water, motor vehicle exhausts, unchecked wastes of factories, and additionally the remnants of the Gulf wars are considered as the main sources of direct exposure of individuals to lead toxic metals. A Spearman rank test confirmed statistically a positive significant correlation between maternal and umbilical 
cord blood for $\mathrm{Pb}, \mathrm{U}$ and Fe elements $(\mathrm{r}=0.749,0.408$ and, 0.502 respectively and $\mathrm{P}<$ 0.01 ). This significant positive correlation indicates that even when the mother has a low level of elements, the placenta cannot prevent these elements to transfer from mother to infant.

Table 2. Maternal and infant quantitative characteristics

\begin{tabular}{|c|c|c|c|c|c|}
\hline Characteristics & \multirow{2}{*}{ Mean \pm SD } & \multirow{2}{*}{ Min, Max) } & \multicolumn{3}{|c|}{ Selected percentiles } \\
\cline { 4 - 5 } & & & $\mathbf{2 5 \%}$ & $\mathbf{5 0 \%}$ & $\mathbf{7 5 \%}$ \\
\hline Maternal Age(years) & $33.3 \pm 7.6$ & $(16,44)$ & 30 & 36 & 39 \\
\hline Body mass index $\left(\mathrm{Kg} / \mathrm{m}^{2}\right)$ & $30.7 \pm 4.8$ & $(18.5,41.1)$ & 27.4 & 30.6 & 34.0 \\
\hline Maternal Hemoglobin $(\mathrm{g} / \mathrm{dL})$ & $9.41 \pm 1.80$ & $(7.0,13.20)$ & 8.00 & 8.75 & 10.90 \\
\hline Umbilical Cord Hemoglobin $(\mathrm{g} / \mathrm{dL})$ & $9.40 \pm 1.74$ & $(7.0,13.20)$ & 8.00 & 8.90 & 11.50 \\
\hline Systolic pressure $(\mathrm{mmHg})$ & $117.0 \pm 10.2$ & $(100,150)$ & 110 & 117 & 120 \\
\hline Diastolic Pressure(mmHg) & $74.1 \pm 6.2$ & $(60,90)$ & 70 & 70 & 80 \\
\hline Pregnancy heart rate $(\mathrm{bpm})$ & $101.0 \pm 22.2$ & $(76,155)$ & 86 & 93 & 116 \\
\hline Fetal heart rate(bpm) & $120.0 \pm 5.3$ & $(120,144)$ & 130 & 135 & 137 \\
\hline GA at delivery $(\mathrm{weeks})$ & $38.6 \pm 1.3$ & $(35,41)$ & 38 & 39 & 40 \\
\hline Birth Weight $(\mathrm{Kg})$ & $2.94 \pm 0.93$ & $(2,4.80)$ & 2.22 & 2.45 & 3.93 \\
\hline Birth Length $(\mathrm{cm})$ & $39.02 \pm 6.8$ & $(30,53)$ & 34.3 & 35.9 & 46.3 \\
\hline Head Circumference $(\mathrm{cm})$ & $35.5 \pm 2.3$ & $(30,39.10)$ & 34 & 35 & 37.9 \\
\hline Placenta Weight $(\mathrm{gm})$ & $481.05 \pm 201.58$ & $(300,895)$ & 320 & 360 & 709.3 \\
\hline
\end{tabular}

Table 3. Trace of heavy elements concentration in maternal and cord blood samples.

\begin{tabular}{|c|c|c|c|c|c|c|c|c|}
\hline \multirow{2}{*}{ Elements } & \multicolumn{4}{|c|}{ Maternal (n= 50) } & \multicolumn{3}{c|}{ Umbilical Cord (n= 50) } & \multicolumn{2}{c|}{$\begin{array}{c}\text { Statistical } \\
\text { Correlations }\end{array}$} \\
\cline { 2 - 9 } & Mean & SD & Min, Max & Mean & SD & Min, Max & r & P - Value \\
\hline $\mathrm{Pb}$ & 1.21 & 0.84 & $0.009,2.98$ & 1.18 & 0.77 & $0.007,2.24$ & 0.749 & $<0.01^{*}$ \\
\hline $\mathrm{U}$ & 0.95 & 0.62 & $0.22,3.00$ & 0.68 & 0.39 & $0.12,2.51$ & 0.408 & $<0.01^{*}$ \\
\hline $\mathrm{Fe}$ & 0.50 & 0.37 & $0.06,1.78$ & 1.27 & 0.91 & $0.04,4.31$ & 0.502 & $<0.01^{*}$ \\
\hline
\end{tabular}

Notes: * refers to the significant results.

Table 4 and Figure 2 illustrates the average value of lead and iron absorption in the maternal and umbilical cord blood samples. It is obvious from this table that the mean value of iron absorption is higher than the mean values of other elements. Results shwed statistically significant correlation between maternal and umbilical cord

Table 4. Absorption of heavy elements in maternal and cord blood samples.

\begin{tabular}{|c|c|c|c|c|c|c|c|c|}
\hline \multirow{2}{*}{ Elements } & \multicolumn{3}{|c|}{ Maternal (n= 50) } & \multicolumn{3}{c|}{ Umbilical Cord (n= 50) } & \multicolumn{3}{c|}{$\begin{array}{c}\text { Statistical } \\
\text { Correlation }\end{array}$} \\
\cline { 2 - 9 } & Mean & SD & Min, Max & Mean & SD & Min, Max & r & P - Value \\
\hline $\mathrm{Pb}$ & 0.041 & 0.006 & $0.001,0.034$ & 0.021 & 0.005 & $0.0001,0.037$ & 0.354 & $<0.05 *$ \\
\hline $\mathrm{Fe}$ & 0.031 & 0.030 & $0.003,0.729$ & 0.071 & 0.130 & $0.002,1.633$ & 0.440 & $<0.05 *$ \\
\hline
\end{tabular}

Notes: * refers to the significant results. 
Table 5 shows the linear regression models for each anthropometric measurements of the newborns (birth weight, birth length and head circumference) retrograde separately for the maternal and umbilical cord blood trace elements levels. The high value of $(\mathrm{B}=-7.78)$ for $\mathrm{Pb}$ concentration in maternal represent that the dependent variable (BL) decreased of (7.78) for every one unit increase in $\mathrm{Pb}$ level with significant correlation and $\mathrm{CI}(-8.97,-6.60)$. This indicate that any increased of $\mathrm{Pb}$ exposure will influence to the anthropometric measurements, and we expected that $(\mathrm{BW})$ increase of (0.3) for every one unit increase in $\mathrm{Fe}$ level in maternal for the low value of $(\mathrm{B}=0.30)$. Beta coefficients are used to compare the relative strength of the various prédictions with the model. $\mathrm{Pb}$ in maternel for dependent variable (BW) has the larges beta coefficient $(-0.91)$ with a negative signifiant correlation and $\mathrm{CI}(-1.23,-0.95)$, Fe in umbilical cord for dependent variable (BL) has the smallest beta $(0.25)$ with a positive non significant correlation and CI $(-0.56,9.67)$. Thus, one standard deviation decrease in $\mathrm{Pb}$ level leads to increase (0.91) in standard deviation of (BW) and one standard deviation increase in $\mathrm{Fe}$ level leads to increase $(0.25)$ standard deviation in predicted (BL).

We spotted significant correlation between the $\mathrm{Pb}, \mathrm{U}$ and $\mathrm{Fe}$ level with anthropometric measurements in maternal and umbilical cord blood $(\mathrm{P}<0.05)$, while non-significant correlation was found between $U, F e$ in umbilical cord with birth length $(p>0.05)$. The negative correlation was found between the $\mathrm{Pb}$ and $\mathrm{U}$ with the anthropometric measurements in maternal and umbilical cord and positive with Fe.

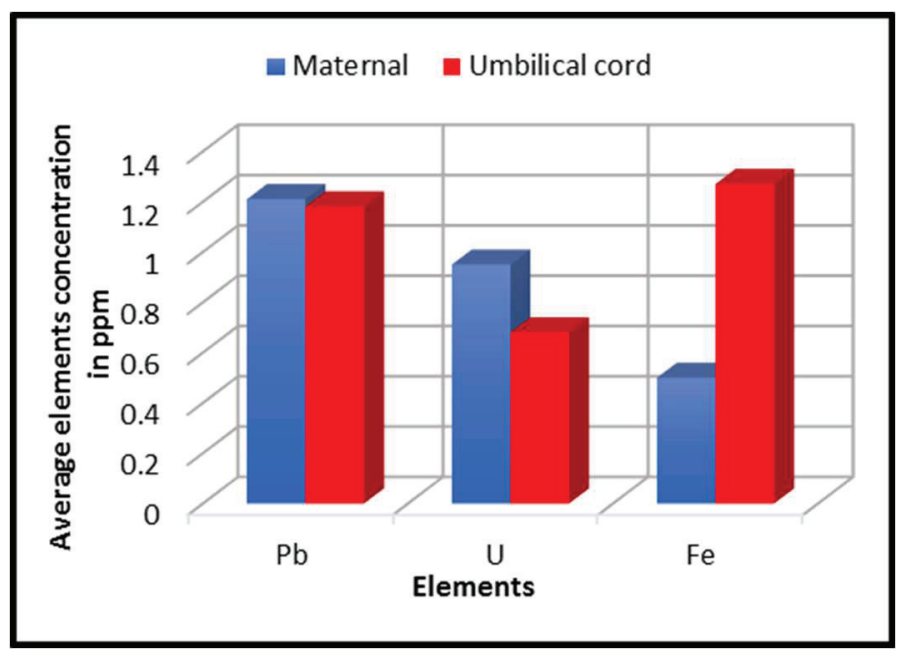

Fig. 1. Trace elements concentrations in blood samples of maternal and umbilical cord 
Table 5. Models for adjusted regression coefficients of element levels in maternal and umbilical cord blood for birth outcomes

\begin{tabular}{|c|c|c|c|c|c|c|c|}
\hline \multirow[t]{2}{*}{ Position } & \multirow[t]{2}{*}{$\begin{array}{l}\text { Dependent } \\
\text { Variables }\end{array}$} & \multicolumn{2}{|c|}{$\begin{array}{c}\text { Unstandardized } \\
\text { Coefficients }\end{array}$} & \multirow{2}{*}{$\begin{array}{c}\begin{array}{c}\text { Standardized } \\
\text { Coefficients }\end{array} \\
\text { Beta } \\
\end{array}$} & \multirow[t]{2}{*}{$\begin{array}{c}95 \% \\
\text { CI }\end{array}$} & \multirow[t]{2}{*}{$\mathbf{t}$} & \multirow[t]{2}{*}{ P - Value } \\
\hline & & B & S.E. & & & & \\
\hline \multirow{3}{*}{$\begin{array}{c}(\mathrm{Pb}) \\
\text { Maternal }\end{array}$} & BW & -1.09 & 0.07 & -0.91 & $(-1.23,-0.95)$ & -15.13 & $\mathrm{P}<0.05^{*}$ \\
\hline & $\mathrm{BL}$ & -7.78 & 0.59 & -0.89 & $(-8.97,-6.60)$ & -13.22 & $\mathrm{P}<0.05^{*}$ \\
\hline & $\mathrm{HC}$ & -2.14 & 0.3 & -0.72 & $(-2.74,-1.55)$ & -7.23 & $\mathrm{P}<0.05^{*}$ \\
\hline \multirow{3}{*}{$\begin{array}{c}(\mathrm{Pb}) \\
\text { Umbilical } \\
\text { Cord }\end{array}$} & BW & -0.85 & 0.10 & -0.77 & $(-1.10,-0.64)$ & -8.23 & $\mathrm{P}<0.05^{*}$ \\
\hline & $\mathrm{BL}$ & -6.12 & 0.77 & -0.76 & $(-2.98,0.74)$ & -7.98 & $\mathrm{P}<0.05^{*}$ \\
\hline & $\mathrm{HC}$ & -2.04 & 0.26 & -0.75 & $(-2.57,-1.52)$ & -7.80 & $\mathrm{P}<0.05^{*}$ \\
\hline \multirow{3}{*}{$\begin{array}{c}(\mathrm{U}) \\
\text { Maternal }\end{array}$} & BW & -0.58 & 0.2 & -0.37 & $(-0.95,-0.15)$ & -2.28 & $\mathrm{P}<0.05^{*}$ \\
\hline & $\mathrm{BL}$ & -3.62 & 1.48 & -0.33 & $(-6.60,-0.64)$ & -2.51 & $\mathrm{P}<0.05^{*}$ \\
\hline & $\mathrm{HC}$ & -1.61 & 0.48 & -0.42 & $(-2.51,-0.58)$ & -3.19 & $\mathrm{P}<0.05^{*}$ \\
\hline \multirow{3}{*}{$\begin{array}{c}(\mathrm{U}) \\
\text { Umbilical } \\
\text { Cord }\end{array}$} & BW & -0.70 & 0.32 & -0.31 & $(-1.38,-0.08)$ & -2.32 & $\mathrm{P}<0.05^{*}$ \\
\hline & $\mathrm{BL}$ & -4.61 & 2.39 & -0.27 & $(-9.43,0.20)$ & -1.90 & $\mathrm{P}>0.05$ \\
\hline & $\mathrm{HC}$ & -1.73 & 0.80 & -0.30 & $(-3.33,-0.10)$ & -2.11 & $\mathrm{P}<0.05^{*}$ \\
\hline \multirow{3}{*}{$\begin{array}{c}(\mathrm{Fe}) \\
\text { Maternal }\end{array}$} & BW & 0.30 & 0.14 & 0.30 & $(0.02,0.58)$ & 2.18 & $\mathrm{P}<0.05^{*}$ \\
\hline & $\mathrm{BL}$ & 2.29 & 1.02 & 0.31 & $(0.24,4.34)$ & 2.24 & $\mathrm{P}<0.05^{*}$ \\
\hline & $\mathrm{HC}$ & 0.88 & 0.34 & 0.35 & $(0.19,1.56)$ & 2.58 & $\mathrm{P}<0.05^{*}$ \\
\hline \multirow{3}{*}{$\begin{array}{c}(\mathrm{Fe}) \\
\text { Umbilical } \\
\text { Cord }\end{array}$} & $\mathrm{BW}$ & 0.81 & 0.34 & 0.33 & $(0.13,1.49)$ & 2.40 & $\mathrm{P}<0.05^{*}$ \\
\hline & $\mathrm{BL}$ & 4.56 & 2.54 & 0.25 & $(-0.56,9.67)$ & 1.79 & $\mathrm{P}>0.05$ \\
\hline & $\mathrm{HC}$ & 2.04 & 0.84 & 0.33 & $(0.36,3.72)$ & 2.45 & $\mathrm{P}<0.05^{*}$ \\
\hline
\end{tabular}

$* \mathrm{BW}=$ birth weight, $\mathrm{BL}=$ birth length, $\mathrm{HC}=$ head circumference

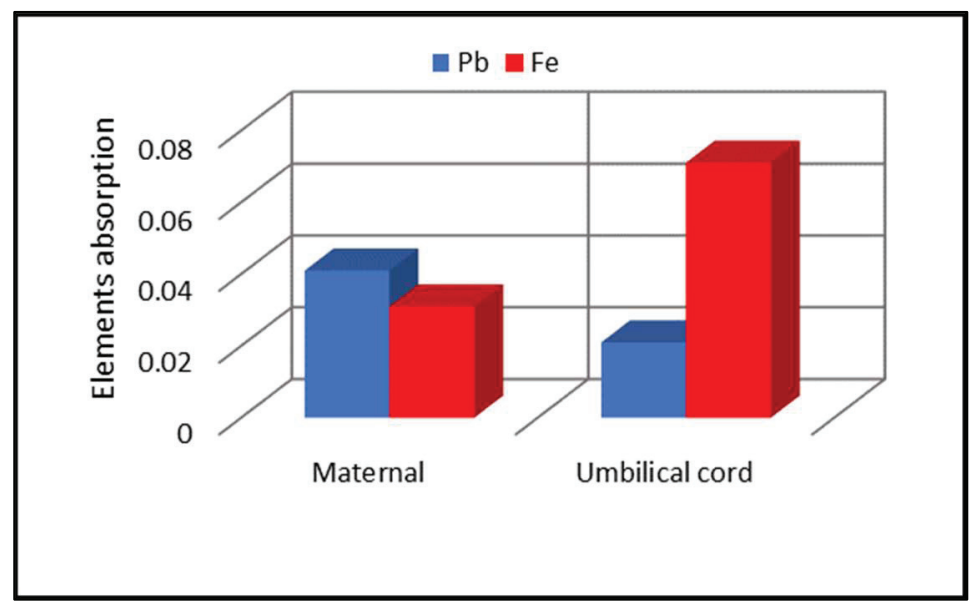

Fig. 2. Absorption of elements in blood samples of maternal and umbilical cord 


\section{Conclusion}

The results evidence the importance of $\mathrm{U}, \mathrm{Fe}$ and $\mathrm{Pb}$ levels in the maternal and umbilical on birth weight. There may be many parameters acting interpret to trigger the condition of low birth weight, and perhaps low birth weight acts merely as a marker of a number of biological lesion. The findings of this study suggest that $\mathrm{U}$ and $\mathrm{Pb}$ could be specimen of these factors. In Iraq, the present study prepares a base line data on $\mathrm{U}$ and $\mathrm{Pb}$ concentration and absorption in maternal and umbilical cord samples. Because concentration and absorption of these elements in blood samples are not routinely measured in any health facility. As a result, there are limited data about the propagation and predictors of high blood levels in both general population and high-risk groups including women in childbearing age. Statistically significant positive correlation between maternal and umbilical cord indicates that even when the mother has a low level of elements, placenta cannot prevent these elements to transfer from mother to infant. It was noted that most anthropometric measurements have a négative significant correlation with $\mathrm{U}, \mathrm{Pb}$ and $\mathrm{Fe}$ concentration in maternal and umbilical cord blood.

\section{Acknowledgement}

The authors thank to short-term grant of Universiti Sains Malaysia (304/PFIZIK/6312125, 304/PFIZIK/6313249, and 304/PJJAUH/6313152) for funding of this project.

\section{References}

1. D. J. Barker, J. Hypertens. 10, S45 (1992)

2. G. C. Burdge,K. A. Lillycrop, Annu. Rev. Nutr. 30, 315 (2010)

3. P. D. Gluckman, M. A. Hanson, C. Cooper, K. L. Thornburg, N Engl J Med. 359, $61(2008)$

4. E. Lurbe, C. Garcia-Vicent, M. I. Torro, F. Aguilar, J. Redon, Hypertension. 63, 1326 (2014)

5. $\quad$ P. M. Nilsson, E. Lurbe, S. Laurent, J. Hypertens. 26, 1049 (2008)

6. K. R. Risnes, L. J. Vatten, J. L. Baker, K. Jameson, U. Sovio, E. Kajantie, M. Osler, R. Morley, M. Jokela, R. C. Painter, Int. J. Epidemiol. 40, 647 (2011)

7. O. Kontic-Vucinic, N. Sulovic, N. Radunovic, Int. J. Fertil. Womens Med. 51, 116 (2006)

8. P. Grandjean, D. Bellinger, Å. Bergman, S. Cordier, G. Davey-Smith, B. Eskenazi, D. Gee, K. Gray, M. Hanson, P. Van den Hazel, Basic Clin. Pharmacol. Toxicol. 102, 73 (2008)

9. M. Vrijheid, M. Casas, A. Bergström, A. Carmichael, S. Cordier, M. Eggesbø, E. Eller, M. P. Fantini, M. F. Fernández, A. Fernández-Somoano, Environmental health perspectives. 120, 29 (2012)

$10 . \quad$ B. L. Gulson, K. J. Mizon, M. J. Korsch, J. M. Palmer, J. B. Donnelly, Sci. Total Environ. 303, 79 (2003)

11. W. Mertz, Science. 213, 1332 (1981)

12. K. Ohtaki, Y. Kodama, M. Nakano, M. Itoh, A. Awa, J. Cologne, N. Nakamura, Radiat. Res. 161, 373 (2004)

13. B. Eskenazi, A. Bradman, R. Castorina, Find this article online. (1999)

14. S. Lin, S.-A. Hwang, E. G. Marshall, D. Marion, Am. J. Epidemiol. 148, 173 (1998)

15. N. Nashashibi, E. Cardamakis, G. Bolbos, V. Tzingounis, Gynecol. Obstet. Invest. 48, 158 (1999)

16. D. C. Bellinger, Curr. Opin. Pediatr. 20, 172 (2008) 
17. I. Hertz-Picciotto, M. Schramm, M. Watt-Morse, K. Chantala, J. Anderson, J. Osterloh, Find this article online. (2000)

18. E. K. Silbergeld, Environ. Health Perspect. 91, 63 (1991)

19. T. M. Leazer, Y. Liu, C. D. Klaassen, Toxicol. Appl. Pharmacol. 185, 18 (2002)

20. S. N. Al-Azzawi, Global research. 1, 4 (2006)

21. M. Al-Sabbak, S. Sadik Ali, O. Savabi, G. Savabi, S. Dastgiri, M. Savabieasfahani, Bull. Environ. Contam. Toxicol., 1 (2012)

22. I. Al-Saleh, M. A. Khalil, A. Taylor, Arch. Environ. Health. 50, 66 (1995)

23. B. Kirel, M. Aksit, H. Bulut, Turk J Pediatr. 47, 125 (2005)

24. R. Iranpour, A. A. Besharati, F. Nasseri, M. Hashemipour, M. Balali-Mood, R. Kelishadi, Saudi. Med. J. 28, 877 (2007)

25. A. A. Al-Jawadi, Z. W. Al-Mola, R. A. Al-Jomard, BMC Res. Notes. 2, 47 (2009)

26. H. Guan,F. Piao, Acta Obstet. Gynecol. Scand. Suppl. 90, 924 (2011)

27. M. Zhu, E. F. Fitzgerald, K. H. Gelberg, S. Lin, C. M. Druschel, Environ. Health Perspect. 118, 1471 (2010)

28. I. Al-Saleh, N. Shinwari, A. Mashhour, G. E. D. Mohamed, A. Rabah, IInt J Hyg Environ Health. 214, 79 (2011)

29. X. Xie, G. Ding, C. Cui, L. Chen, Y. Gao, Y. Zhou, R. Shi, Y. Tian, Environ. Sci. Pollut. Res. 175, 30 (2013)

30. R. Raghunath, R. Tripathi, V. Sastry, T. Krishnamoorthy, Sci. Total Environ. 250, 135 (2000)

31. E. García-Esquinas, B. Pérez-Gómez, P. Fernández-Navarro, M. A. Fernández, C. De Paz, A. M. Pérez-Meixeira, E. Gil, A. Iriso, J. C. Sanz, J. Astray, BMC Public Health. 13, 841 (2013)

32. S. Turgut, S. Hacioğlu, G. Emmungil, G. Turgut, A. Keskin, POL J ENVIRON STUD. 18 (2009)

33. S. Llop, X. Aguinagalde, J. Vioque, J. Ibarluzea, M. Guxens, M. Casas, M. Murcia, M. Ruiz, A. Amurrio, M. Rebagliato, Sci. Total Environ. 409, 2298 (2011)

34. A. K. M. Tiwari, A. A. Mahdi, F. Zahra, S. Sharma, M. P. S. Negi, Indian J. Clin. Biochem. 27, 246 (2012)

35. M. H. R. Al-sahlanee, R. M. Ramli, M. A. H. Ali, N. F. Tawfiq, A. A. Rahman, I. S. Mustafa, N. Z. N. Azman, N. N. A. N. A. Razak, N. Z. Yahaya, H. M. Al-Marri, in Control System, Computing and Engineering (ICCSCE), 2016 6th IEEE International Conference on. (IEEE, 2016), pp. 360

36. R. L. Fleischer, P. B. Price, R. M. Walker, Nuclear tracks in solids: principles and applications. (Univ of California Press, 1975)

37. S. A. Durrani,R. K. Bull, Solid state nuclear track detection: principles, methods and applications. (Elsevier, 2013) 